\title{
LONGEVITY OF BURIED RAGWORT SEED IN FOUR SOILS
}

\author{
T.K. JAMES and A. RAHMAN \\ AgResearch, Ruakura Research Centre, Private Bag 3123, Hamilton
}

\begin{abstract}
The viability of ragwort (Senecio jacobaea L.) seed buried for several years at $0-2,4-6$ and $19-21 \mathrm{~cm}$ depths was evaluated in four different soil types. Seed samples in nylon mesh bags were removed after $1,2,3,5,11$ and 16 years burial and their viability determined by germination. After 16 years no viable seed was found in the clay soil. In the silt loam and peat soils $1-3 \%$ viable seed remained while in the sandy soil up to $13 \%$ remained viable. In the surface $0-2$ $\mathrm{cm}$ layer of soil it took from 10.9 to 14.6 years for the percentage of viable seed to fall to $1 \%$ of the original viable seed, depending on soil type. At the $4-6$ and $19-21 \mathrm{~cm}$ depths the corresponding times were $12.8-16.5$ years and $13.0-18.0$ years.
\end{abstract}

Keywords: ragwort, Senecio jacobaea, buried seed, seed longevity, weed seed.

\section{INTRODUCTION}

Ragwort (Senecio jacobaea L.) is a herbaceous plant, native to Europe, but now widespread throughout New Zealand. Its presence was first recorded near Dunedin in 1874 (Poole and Cairns 1940). Ragwort is a significant pastoral weed because it competes vigorously for space and also accumulates pyrrolizidine alkaloids that are toxic to stock (Wardle 1987). For these reasons ragwort is classified as a Plant Pest of Regional Significance or a Boundary Control Plant by many Regional Councils. Under normal conditions ragwort grows as a biennial but if its growth is stunted through grazing or by herbicides it frequently turns into a perennial, multicrown plant that is difficult to control.

Although ragwort exhibits some vegetative regrowth from broken roots and damaged crowns, its principal means of reproduction and dispersal is by seed (Schmidl 1972). A prolific producer of seed, a large ragwort plant can bear as many as 300,000 seeds. The seeds are released with a pappus attached for dispersal by wind but most seeds actually drop within a few metres (Poole and Cairns 1940).

The deposition of large quantities of seed in a small area has the potential to create a very large localised seedbank in the soil. The persistence of these seeds in the soil seedbank is influenced by a number of factors. Two important factors are seed burial depth and soil type (Forcella 1992; Roberts and Feast 1972). Other factors include differences in soil moisture, temperature, light and aeration within the soil profile, all of which influence seed survival by processes such as ageing, fungal parasitism and faunal predation (Buhler et al. 1998).

The fact that ragwort can form dense infestations that persist for many years indicates that there is a ready supply of seed in the soil. The knowledge of germination behaviour (i.e. the timing and pattern of germination and seed dormancy) is important because seedlings are more vulnerable to control methods than mature plants and therefore are an easier target in any weed management system (Wardle 1987; Forcella 1992).

This paper reports the results of an experiment aimed at evaluating the effect of burial depth and soil type on the viability of ragwort seed, conducted at four sites with similar climate but widely varying soil characteristics. 


\section{MATERIALS AND METHODS}

Four soil types commonly found in the Waikato region were selected for this study (Table 1). The Horotiu and Dunmore soils are both well drained, the Hamilton clay loam is moderately well drained and the Rukuhia peat is very poorly drained. In June 1981 for each site, 90 sets of $0.06 \mathrm{~g}$ (250) of freshly gathered ragwort seed were each mixed with heat sterilised soil $(60 \mathrm{~g})$ collected from the site and 60 sets were placed in fine nylon mesh bags $(0.25 \mathrm{~mm}$ mesh). Thirty tubes for each site $(25 \mathrm{~cm}$ length of perforated, $6 \mathrm{~cm}$ diameter plastic drainpipe) were filled with non-sterilised soil from the site. During this process, two seed/soil bags were placed in each tube at $4-6 \mathrm{~cm}$ and $19-21 \mathrm{~cm}$ from the top end of the pipe. The top $2 \mathrm{~cm}$ of the pipe was left free of soil and an unbagged seed/soil mixture was placed there, separated from the soil below by a layer of fine nylon mesh but uncovered at the top. The pipe sections were then buried vertically in the appropriate soil type with their tops flush with the soil surface. The tubes were arranged in a regular $10 \times 3$ matrix at $20 \mathrm{~cm}$ centres. The burial sites were in permanent pasture that was regularly grazed or mown.

TABLE 1: Descriptions and some characteristics of the soils used for this study.

\begin{tabular}{|c|c|c|c|c|c|c|}
\hline Soil & $\%$ sand & $\%$ clay & $\% \mathrm{OC}^{1}$ & $\mathrm{pH}$ & $\begin{array}{c}\mathrm{CEC}^{1} \\
\mathrm{meq} / 100 \mathrm{~g}\end{array}$ & $\begin{array}{l}\text { Field capacity } \\
(\% \text { v/v })\end{array}$ \\
\hline Horotiu sandy loam & 61 & 15 & 8.7 & 5.4 & 37.4 & 44.8 \\
\hline Dunmore silt loam & 54 & 17 & 9.5 & 5.5 & 51.7 & 66.7 \\
\hline Rukuhia peat & 24 & 16 & 49.1 & 4.6 & 103.6 & 60.7 \\
\hline Hamilton clay loam & 29 & 31 & 4.6 & 5.6 & 28.2 & 36.8 \\
\hline
\end{tabular}

${ }^{1} \mathrm{OC}=$ Organic carbon; $\mathrm{CEC}=$ Cation exchange capacity.

At 2 - 4 monthly intervals for the first three years after burial, emerged seedlings were counted and removed from the tops of the pipe sections. After 1, 2, 3, 5, 11 and 16 years, three randomly selected pipes (one per row) were retrieved from each site in June or July and the viable seed from each depth counted. Seed viability was determined by germination in an unheated glasshouse. The contents of each nylon bag and the $0-2 \mathrm{~cm}$ layer were spread thinly $(2-4 \mathrm{~mm})$ on paper towels laid over damp vermiculite in a tray. At approximately monthly intervals, emerged ragwort seedlings were counted and removed. The soil was then thoroughly mixed and the procedure repeated until no further seedlings emerged (4 - 6 months).

\section{RESULTS AND DISCUSSION}

The viability of the original seed (collected in autumn 1981), as determined by the Official Seed Testing Station, Palmerston North, was $69 \%$ and is in keeping with that determined by Poole and Cairns (1940). This value was used to estimate the initial number of viable seeds (172) buried at each depth.

Results from the four sites show that seed viability was affected primarily by burial depth. The ragwort seed mixed in the top $2 \mathrm{~cm}$ of the soil initially disappeared at a faster rate that that at $4-6$ and $19-21 \mathrm{~cm}$ depths (Fig. 1). The patterns of viable seed loss were also different at the different depths. At the surface $(0-2 \mathrm{~cm})$ the seed loss is best described by a normal exponential decay curve while the disappearance of the seed buried deeper $(4-6$ and $19-21 \mathrm{~cm}$ ) is best described by linear decay (Fig.1, Table 2). One reason for this could be a greater level of predation of the surface seed as well as loss through germination. There were significant germination events soon after the seed was buried and again in the second spring of the trial (Fig. 2). The germination was similar in all four soils and itself accounted for about $10 \%$ of the viable seed. This, combined with seed that germinated but failed to establish and some increase in predation or rotting of seed can readily explain the initial rapid disappearance of the ragwort seed from the surface which is seen in the exponential decay pattern. Some researchers have reported that seed buried at greater depths would be expected 


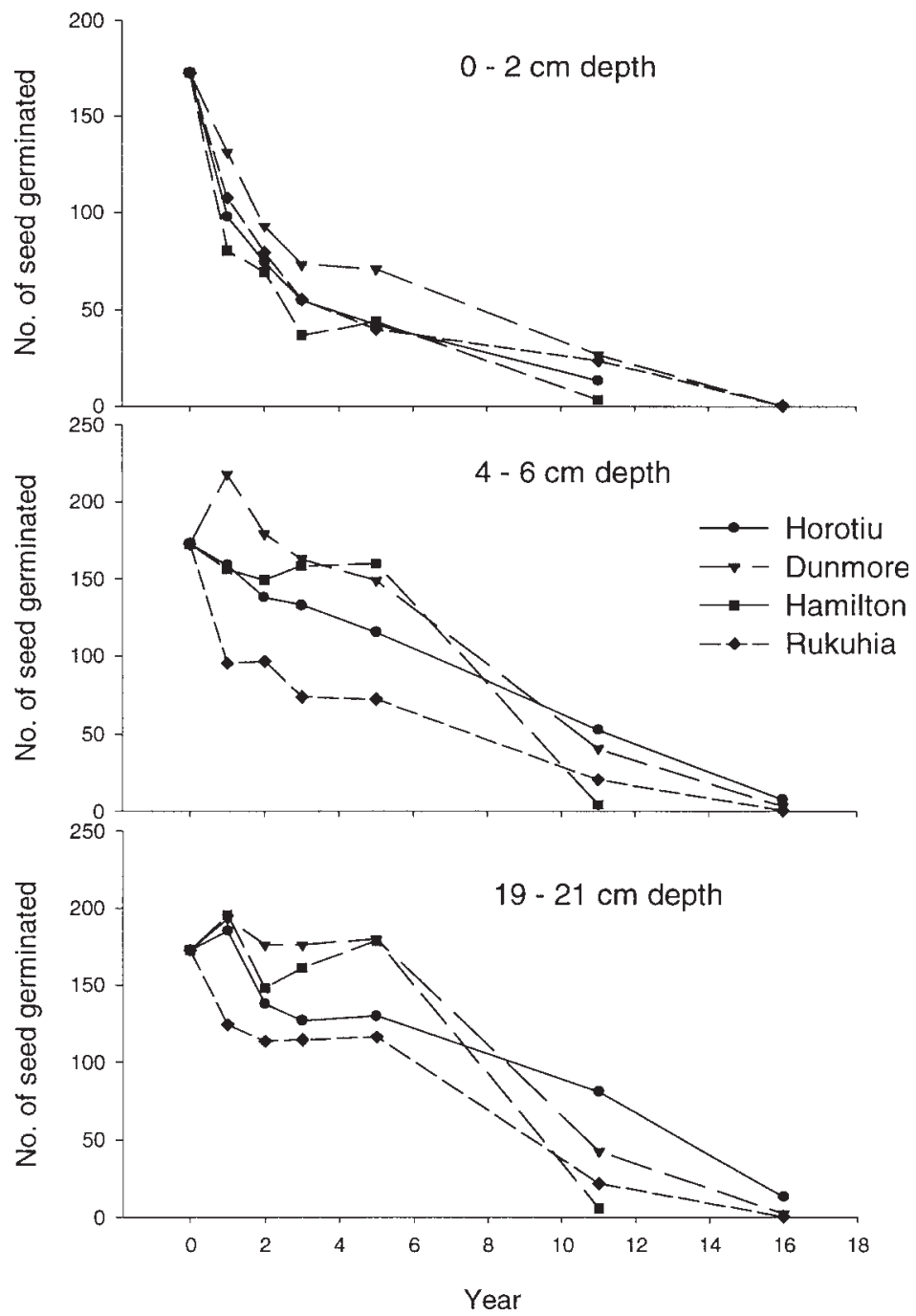

FIGURE 1: Mean number of ragwort seeds which germinated after recovery from being buried at $0-2 \mathrm{~cm}, 4-6 \mathrm{~cm}$ and $19-21 \mathrm{~cm}$ depths in four different soils. A terminated line indicates that no seed germinated at the final sampling date.

to show similar decay patterns (Lewis 1973; Egley and Chandler 1983). However, high levels of variability are often encountered in buried seed studies, and there was little difference between an exponential and a linear decay model in describing the data.

After being buried for 16 years, very little of the ragwort seed remained viable in any of the four soils (Fig. 1). At years 11 and 16 there were no significant differences in the number of viable seeds at the different depths. To obtain a better comparison of the effects of soil type the theoretical time for the number of viable seeds to be reduced 


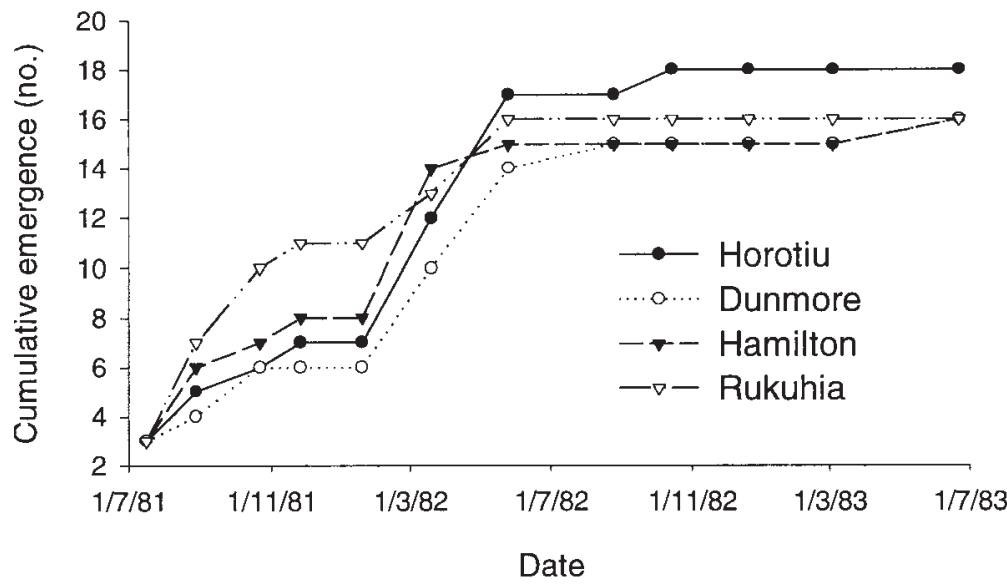

FIGURE 2: Cumulative emergence of ragwort from the $0-2 \mathrm{~cm}$ depth, during the first 2 years, in four different soils (average of three replicates).

to $1 \%$ of the original number was calculated, and results are presented in Table 2 along with the $\mathrm{R}^{2}$ of the fit. For the surface seed this was achieved by fitting regression lines to logarithmic transformed data, while for the other depths regression lines were fitted to the raw data. For most of the results the $95 \%$ prediction error is within plus or minus 2 years. The effect of forcing the seed viability data for the $4-6$ and $19-21 \mathrm{~cm}$ depths into an exponential model would be to extend the prediction period by about three years. Also, in this study the estimate of the longevity of the seed buried at the $4-6$ and $19-21 \mathrm{~cm}$ depths is possibly overestimated as the seed/soil mix was enclosed in a nylon mesh bag preventing predation by foraging invertebrates.

TABLE 2: Predicted time (years) for viable ragwort seed numbers to be reduced to $1 \%$ of original viable seeds in the four soil types at three depths.

\begin{tabular}{|c|c|c|c|c|c|c|c|c|}
\hline \multirow{3}{*}{$\begin{array}{l}\text { Soil } \\
\text { depth } \\
\text { (cm) }\end{array}$} & \\
\hline & \multicolumn{2}{|c|}{ Horotiu } & \multicolumn{2}{|c|}{ Dunmore } & \multicolumn{2}{|c|}{ Rukuhia } & \multicolumn{2}{|c|}{ Hamilton } \\
\hline & Years & $\mathrm{R}^{2}$ & Years & $\mathrm{R}^{2}$ & Years & $\mathrm{R}^{2}$ & Years & $\mathrm{R}^{2}$ \\
\hline $0-2^{1}$ & 12.1 & 0.9606 & 14.6 & 0.8507 & 14.1 & 0.8598 & 10.9 & 0.9487 \\
\hline $4-6^{2}$ & 16.5 & 0.9933 & 15.6 & 0.9393 & 14.3 & 0.7986 & 12.8 & 0.8338 \\
\hline $19-21^{2}$ & 18.0 & 0.9371 & 16.1 & 0.9142 & 14.9 & 0.9214 & 13.0 & 0.7876 \\
\hline
\end{tabular}

${ }^{1}$ Determined using exponential decay model.

${ }^{2}$ Determined using linear decay model.

The only soil type that showed significant differences in persistence at different burial depths was the Horotiu soil, where the surface seed disappeared slightly faster compared to those buried at greater depths. However, in general soil type and burial depth had little effect on the longevity of ragwort seed. These results are similar to those obtained by Thompson and Makepeace (1983) who calculated $19-21$ years for reduction to $1 \%$ viability in a clay loam and $11-13$ years in a silt loam soil at depths from $4-21 \mathrm{~cm}$, based on a six-year study. However, in the $0-2 \mathrm{~cm}$ layer, they determined ragwort seed persistence to be about half of that found in this study. 
These results differ markedly from those reported for nodding thistle (Carduus nutans) and giant buttercup (Ranunculus acris) in the same soil types (James et al. 1998; James and Rahman 1999). Seeds of both these weeds persisted for longer at the $19-21 \mathrm{~cm}$ depth and disappeared more quickly from the surface layer.

The relatively long persistence of viable ragwort seed in the surface layer of the soil poses some management problems for this weed. If additions of fresh seed to the soil are eliminated, the remaining viable seed could still produce infestations of ragwort for more than 10 years.

\section{ACKNOWLEDGEMENTS}

The authors wish to thank Alex Thompson who carried out the seed burial and collected the data for the first five years.

\section{REFERENCES}

Buhler, D.D., Hartzler, R.G. and Forcella, F., 1998. Weed seed bank dynamics: implications to weed management. J. Crop Production 1: 145-168.

Egley, G.H. and Chandler, J.M., 1983. Longevity of weed seeds after 5.5 years in the Stoneville 50-year buried-seed study. Weed Sci. 31: 264-270.

Forcella, F., 1992. Prediction of weed seedling densities from buried seed reserves. Weed Res. 32: 29-38.

James, T.K., Rahman, A., Wardle, D.A. and Bonner, K.I., 1998. Survival of nodding thistle (Carduus nutans) seed buried at different depths in four soils. Proc. 51st N.Z. Plant Prot. Conf: :33-37.

James, T.K. and Rahman, A., 1999. Survival of giant buttercup seeds buried at different depths in four soils. Proc. 52nd N.Z. Plant Prot. Conf:: 234-239.

Lewis, J., 1973. Longevity of crop and weed seeds: survival after 20 years in soil. Weed Res. 13: 179-191.

Poole, A.L. and Cairns, D., 1940. Botanical aspects of Ragwort (Senecio jacobaea L.). Bulletin No. 82. E.V. Paul, Government Printer, Wellington, N.Z. 62 p.

Roberts, H.A. and Feast, P.M., 1972. Fate of seeds of some annual weeds in different depths of cultivated and undisturbed soil. Weed Res. 12: 316-324.

Schmidl, L., 1972. Biology and control of ragwort, Senecio jacobaea L., in Victoria, Australia. Weed Res. 12: 37-45.

Thompson, A. and Makepeace, W., 1983. Longevity of buried ragwort (Senecio jacobaea L.) seed. N. Z. J. Exp. Agr. 11: 89-90.

Wardle, D.A., 1987. The ecology of ragwort (Senecio jacobaea L.) - a review. N.Z. J.Ecol.10: 67-76. 